\title{
The Implementation of Multicultural Educational Communication within the Islamic Education and Character Development (IECD) Subject at Elementary Schools in Indonesia
}

\author{
Dwi Kartikawati \\ Faculty of Social and Political Sciences, Universitas Nasional, Jakarta, Indonesia
}

http://dx.doi.org/10.18415/ijmmu.v6i2.693

\begin{abstract}
In the educational sector, effective communication is a crucial instrument to inculcate multicultural values. One of the methods involves integrating these values into the Islamic Education and Character Development (IECD) subject in elementary schools. This research focused on how to implement this method in SD Badan Perguruan Indonesia (BPI) in Bandung, Indonesia by using a qualitative case study approach with an intensive focus on how and why the subject matter was urgently conducted. The research data were collected by interviews, field observations, literature study and the use of educational communication and Stephen R. Covey's theory of habit as theoretical frameworks. Research results showed that the implementation of multicultural educational communication integrated into IECD by involving educational communication elements, i.e. teachers, learning materials and media as well as students could be attained by developing characters and habits of the students so that they always uphold good moral values, discipline, awareness, humanity and honesty both at school and in the society.
\end{abstract}

Keywords: Educational Communication; Multicultural Values; IECD

\section{Introduction}

Communication in education, according to Yusuf (2010:02), is communication that is specifically designed to improve target audience's added value which in this case is their literacy in technology, communication and information. Specifically, this type of communication covers all aspects of education (Kartikawati, et al: 2018: 62). Its elements include communicators, learning materials, media, communicants and effects. By using educational communication as a theoretical framework, students are expected to appreciate diversity through multicultural learning that will eventually develop their positive attitude towards diversity and create harmony in it.

As we know, education is an effective instrument to develop generations that possess constructive outlook on heterogeneity. This multicultural learning can be implemented by using a progressive approach through the holistic transformation of the society's education and culture as stated in the Law number 20 year 2003 on National Educational System Chapter III Article 4 Verse 1 which reads 
"Education is organized in a democratic and just manner and is not discriminatory by upholding human rights, religious values, cultural values and national diversity."

Multicultural education is based on philosophical ideas about freedom, justice, equality and the protection of human rights (Hakim \& Utari, 2018:2-3). Essentially, it aims to prepare all students to contribute actively in creating equality of the organizations and institutions structures at school. There are four core values of this education (Tilaar, 2003), i.e. (1) Appreciation of cultural diversity in the society; (2) Recognition of humans' dignity, values and rights; (3) Establishment of the world community's responsibilities and (4) Establishment of humans' responsibilities towards planet Earth. The foundations of aforementioned core values are pluralism, humanism, democracy and justice (Aufin, 2014:117). Moreover, it serves a purpose related to attitudes, knowledge and learning (Sapendi, 2015: 98). It is an education strategy applied to all types of subjects by using the diversities amongst the students such as ethnicity, religion, dialect, gender, social class, race, capability and age as examples to facilitate their learning process (Ibrahim, 2013:137).

Islamic teachings in Indonesia are based on multicultural setting due to its diverse ethnicities and dialects (approximately, Indonesia has 300 ethnicities and 200 dialects), religions and beliefs (Islam, Catholic, Protestant, Hinduism, Buddhism and Confucius), gender as well as physical and mental abilities. Based upon this idea, elementary schools have a responsibility to produce pupils that possess a high intellectual understanding of these heterogeneities as well as develop their awareness and respect towards their differences by implementing this educational system.

The curriculum of Islamic education in elementary schools is designed based on the 2013 Curriculum that involves several disciplines to provide a meaningful and broad experience to pupils. This curriculum has four aspects of assessment, i.e. knowledge, skills, attitudes and behavior (Chomaidi \& Salamah, 2018:272). Its purpose is to develop Indonesian people to be faithful, productive, creative, innovative and affective as well as able to contribute to the society, the nation, the state and the world civilization.

In the 2013 Curriculum, character education is integrated in all subjects. Learning materials related to norms or values require to be developed, highlighted and related to the context of everyday life. Hence, Islamic Education has transformed its title to Islamic Education and Character Development (IECD). It is consistent with educational strategies that promote awareness to students regarding diversity through humanist, pluralist, democratic and just manners. In elementary schools, this strategy is conducted by using a thematic-integrative approach.

Multicultural learning integrated to IECD at the primary educational level is conducted by conditioning as suggested by Stephen R. Covey in his theory of habit. He defines habit as the combination of knowledge, skills and desire. Knowledge is a theoretical paradigm that is related to 'what to do' and 'why'. Meanwhile, skills are related to 'how to do' and desire is related to 'want to do' (Zubaidi, 2017:376-377).

Multicultural education in elementary schools must be used as an instrument for teachers to teach their pupils about the diversity around them that comes from culture, social background, language, religion, gender and abilities which should be regarded as an asset.

In this type of education, the most important thing is that teachers must not only master their teaching materials but also be able to indoctrinate the core values of multicultural education. As a result, they can develop their students as individuals who uphold good moral values, discipline, awareness, humanity and honesty in their everyday life, both at school and in the society. 
IECD aims to develop individuals who are not only faithful and devoted, but also as Caliphs on Earth who are able to appreciate diversity around them. Teachers of this subject have a major role as a facilitator for their students to seek information and assist them in finding and believing universal values of Islam. This means, they must be able to motivate and precipitate them to initiatively seek knowledge on the subject matter.

The research was conducted in SD BPI located on Jalan Halimun No. 40, Kelurahan Lingkar Selatan, Kecamatan Lengkong, Bandung, Indonesia. This school was established in 1959 by Badan Perguruan Indonesia (BPI) (English: Indonesian College Board) which is located in Jalan Burangrang No. 8 , Bandung. It was designed as an inclusive school that allows both regular and disabled students to study in the same classroom.

By implementing multicultural educational communication in the IECD subject, students should possess flexibility and resilience when facing adversity of situations and interests that will eventually fortify the national unity. Moreover, they should comprehend and adhere to Islam teachings that uphold compassion (Rahmah), peace (Salam) and tolerance (Tasamuh) within human relations. Based on this background, the research focus lies on how and why multicultural educational communication is implemented in IECD at SD BPI Bandung.

\section{Methodology}

This research used a qualitative method with a case study approach that examined questions of 'how' and 'why'. It was believed to be the most suitable strategy due to limited opportunities to control the investigated subject while the research focus was a phenomenon in a real-life context (Yin, 2004:12).

Data were collected through observations in IECD classes, interviews with the principal of SD BPI as informant 1 and the IECD teacher as informant 2, as well as a documents study. Qualitative data analysis was conducted interactively by collecting data from the field which later reduced by selecting, grouping and eliminating irrelevant and unsupportive ones. Finally, the final data were presented and drawn in conclusion.

\section{Results}

\section{School Profile}

The vision of SD BPI is to develop noble, intelligent and global-minded graduates. Their mission statement is as follows: (1) strive for high quality educational services for all society classes based on faith and piety, science and technology, as well as a global mindset; (2) assist and facilitate the development of students' potencies in accordance to their interests and talents so that they possess life skills built upon the balance of ethics, logic, aesthetic and kinesthetic; (3) improve education services professionally within the spirit of exemplary, cohesiveness, independence and accountability in order to provide excellent services to the community; and (4) improve the quality of learning by creating an active, creative, effective and fun learning atmosphere with a high quality mindset. The school day begins at 07:15 AM with the students attending a flag ceremony followed by some Quran recitation. 


\section{Multicultural Educational Communication in IECD}

Religious education has been included in the curriculum of all educational institutions starting from elementary level to college to serve a great purpose for our young generation. In this case, IECD is a form of a conscious and planned effort to prepare students to recognize, understand, internalize, and believe in the teachings of Islam as well as respect communities of other religions in order to fortify the unity of our nation (Muhaimin, 2008: 76). In other words, IECD is a process of Islamic values and knowledge transformation and internalization by developing students' potencies in order to achieve harmony and perfection in all aspects of their lives (SM Ismail, 2009: 36).

Multicultural educational communication through IECD learning was conducted by involving its integrated elements that included:

\section{Communicators (IECD Teacher)}

The study result obtained from an interview with informant 1 (the school principal) showed that the teacher, as a communicator, should be able to serve as a facilitator with a multicultural mindset that could be implemented by:

- Being open minded and paying a close attention to each student. As an educator, the IECD teacher must become an authoritative figure or a role model whose words and attitudes were taken as examples and followed by his or her students.

- Willing and able to listen to the students. In this case, the teacher must show a friendly figure in front of the students so they would, without being hesitant, ask questions such as why they have to keep the Musala clean, etc.

- Willing to listen to their ideas or opinions.

- Possessing a constructive mindset. For example, a teacher should educate his or her students in a friendly and mindful manner when they neglected their assignments.

- Possessing tolerance and demonstrating the best attitudes in front of the students. The informant 1 stated that SD BPI always encouraged all individuals at school to mutually understand and respect each other as we all were created by God despite our differences.

- Appreciating students' achievements even the smallest one. This is compulsory as in SD BPI, disabled students were placed in the same learning environment as non-disabled ones.

Furthermore, the informant 2 (a $6^{\text {th }}$ grade IECD teacher) asserted that a teacher must:

- Possess competencies in their own field as well as able to understand overall condition of the students.

- Be creative in deciding which method and media to use in order to develop students' competencies.

- Always update their knowledge and able to relate past experiences to the intended competencies and characters.

2. Learning Materials

IECD learning materials should comply with the Lesson Plans that had been designed heretofore. According to Permendikbud No. 81A Year 2013 Attachment IV on General Learning Guidelines, every teacher must compile their Lesson Plans with materials containing multicultural values as asserted by the informant 2:

"According to the 2013 Curriculum, Islamic Education was transformed into Islamic Education and Character Development (IECD). Based on this, we can see that it reflects noble values such as multiculturalism. In order to maintain the linear integration of basic competencies among different classes, students' competencies must be designed by complying with the core competencies that consist 
of: Core Competency-1 (CC-1) for spiritual attitude; Core Competency-2 (CC-2) for social attitude; Core Competency 3 (CC-3) for knowledge attitude; and Core Competency-4 (CC-4) for skills attitude. Regarding IECD, literacy refers to the ability to read the Quran, such as Asma Ul Husna, as it is the basic requirement for Muslim children. Students usually read Asma U1 Husna before the teacher arrives in the classroom. Besides, there is a tradition called "Bandung Masagi" that introduces Sundanese culture by using a religious approach. Students should be enthusiastic in reading their Holy Book rather than playing on their gadgets and this is the responsibility of their parents to control them at home. Moreover, students are taught to be aware of their surroundings and interact with each other in a good manner, not selfish nor individualistic, sympathetic and impartial. This is what I previously called multiculturalism."

The implementation of multicultural values in IECD can be described in the following tables:

Table 1: The Principles of Multiculturalism with their Behavior Manifestation

\begin{tabular}{|l|l|l|l|}
\hline No. & $\begin{array}{l}\text { Multicultural } \\
\text { Principles }\end{array}$ & \multicolumn{1}{|c|}{ Definition } & Behavior Manifestation \\
\hline 1. & Pluralism & $\begin{array}{l}\text { Recognizes religious differences and identity of } \\
\text { others with an intention to eliminate potential } \\
\text { conflicts. }\end{array}$ & $\begin{array}{l}\text { Tolerance, mutual respect, } \\
\text { allowing or accepting different } \\
\text { stances (views, opinions, } \\
\text { beliefs, habits, attitudes, etc.), } \\
\text { honest, and open-minded. }\end{array}$ \\
\hline 2. & Humanism & $\begin{array}{l}\text { Honors and upholds humans' values and dignity. } \\
\text { Regards our existence as a very important matter } \\
\text { above other things in the world. }\end{array}$ & $\begin{array}{l}\text { Being altruistic, humane, show } \\
\text { good manners, humble and } \\
\text { treating others fairly and } \\
\text { impartially. }\end{array}$ \\
\hline 3. & Democracy & $\begin{array}{l}\text { Reflects the way of thinking, behaving and acting } \\
\text { that perceive others' rights and obligations } \\
\text { equally as well as exhibiting freedom within } \\
\text { limits. }\end{array}$ & $\begin{array}{l}\text { Exhibiting the attitude of } \\
\text { freedom in choosing certain } \\
\text { hobbies or interests and being } \\
\text { responsible for the } \\
\text { consequences. }\end{array}$ \\
\hline 4. & Justice & $\begin{array}{l}\text { The assurance of treating others in fair and } \\
\text { impartial manner in spite of their skin color, } \\
\text { group, ethnicity, religion, economic status, } \\
\text { gender, ability, etc. }\end{array}$ & $\begin{array}{l}\text { Possessing impartial and } \\
\text { nonjudgmental attitudes and an } \\
\text { ability to balance rights and } \\
\text { obligations. }\end{array}$ \\
\hline
\end{tabular}


Table 2: Multicultural Values in IECD Learning Materials

\begin{tabular}{|c|c|c|c|}
\hline $\begin{array}{l}\text { The Material of } \\
\text { Chapter (1-9) }\end{array}$ & Description & $\begin{array}{l}\text { Multicultural } \\
\text { Values }\end{array}$ & $\begin{array}{l}\text { Behavioral } \\
\text { Embodiments }\end{array}$ \\
\hline $\begin{array}{l}\text { The Nobility of } \\
\text { Mutual Respect }\end{array}$ & $\begin{array}{l}\text { Surah Al-Kafirun which is the } \\
109^{\text {th }} \text { chapter in the Quran. }\end{array}$ & Pluralism & $\begin{array}{l}\text { Tolerant and } \\
\text { sympathetic towards } \\
\text { others. }\end{array}$ \\
\hline $\begin{array}{l}\text { When the Earth } \\
\text { Stops Spinning }\end{array}$ & $\begin{array}{l}\text { The Judgment Day, the } \\
\text { destruction of the universe and } \\
\text { its contents. }\end{array}$ & Humanism & Humble \\
\hline $\begin{array}{l}\text { The Beautiful } \\
\text { Names of Allah } \\
\text { SWT }\end{array}$ & $\begin{array}{l}\text { Acknowledging the beautiful } \\
\text { names of Allah SWT. }\end{array}$ & Humanism & Being altruistic. \\
\hline Let's Pay Zakat & $\begin{array}{l}\text { The procedure and criteria of } \\
\text { Zakat. }\end{array}$ & Humanism\& Justice & $\begin{array}{l}\text { Exhibiting altruism and } \\
\text { mutual help. }\end{array}$ \\
\hline $\begin{array}{l}\text { The Exemplary } \\
\text { Rasulullah SAW }\end{array}$ & $\begin{array}{l}\text { Take the Prophet Muhammad } \\
\text { SAW as a role model of being } \\
\text { trustworthy (al-Amin). }\end{array}$ & $\begin{array}{l}\text { Pluralism \& } \\
\text { Humanism }\end{array}$ & $\begin{array}{l}\text { Mutual respect and } \\
\text { obedience. }\end{array}$ \\
\hline $\begin{array}{l}\text { The Virtue of } \\
\text { Mutual Help }\end{array}$ & $\begin{array}{l}\text { Surah Al-Maidah Verse } 2 \text { that } \\
\text { teaches us to help each other in } \\
\text { righteousness and piety. }\end{array}$ & $\begin{array}{l}\text { Pluralism \& } \\
\text { Humanism }\end{array}$ & $\begin{array}{l}\text { Tolerant, sympathetic, } \\
\text { alert, thoughtful and } \\
\text { harmonious. }\end{array}$ \\
\hline $\begin{array}{l}\text { Believe in Qada and } \\
\text { Qadar }\end{array}$ & $\begin{array}{l}\text { Believe in Allah SWT's divine } \\
\text { unalterable decree before His } \\
\text { creatures. }\end{array}$ & Justice & $\begin{array}{l}\text { Accepting the results of } \\
\text { our efforts, sincerity. }\end{array}$ \\
\hline $\begin{array}{l}\text { Glad to be } \\
\text { Commendable }\end{array}$ & $\begin{array}{l}\text { Positive thinking of Allah SWT } \\
\text { and human beings. }\end{array}$ & $\begin{array}{l}\text { Pluralism \& } \\
\text { Humanism }\end{array}$ & $\begin{array}{l}\text { Exhibiting tolerance and } \\
\text { sympathy. }\end{array}$ \\
\hline $\begin{array}{l}\text { Let's Pay Infaq and } \\
\text { Sadaqa }\end{array}$ & $\begin{array}{l}\text { Voluntary and spontaneous } \\
\text { charity for impoverished } \\
\text { people. }\end{array}$ & Humanism & Exhibiting altruism. \\
\hline $\begin{array}{l}\text { Proud to Follow the } \\
\text { Prophets and } \\
\text { Ashabul Kahfi's } \\
\text { Role Models }\end{array}$ & $\begin{array}{l}\text { Follow the Prophet Yunus' role } \\
\text { model who invited His people } \\
\text { to worship Allah SWT. }\end{array}$ & $\begin{array}{l}\text { Justice, Democracy } \\
\text { \& Humanism }\end{array}$ & $\begin{array}{l}\text { Demonstrating } \\
\text { responsible attitudes and } \\
\text { compassion. }\end{array}$ \\
\hline
\end{tabular}

Educational communication also promoted an anti-discrimination attitude especially towards the disabled students in SD BPI Bandung due to its inclusive policy. In addition, it also developed inclusive heterogeneity, social care and respect towards diverse dialects. These goals were obtained by having outdoor learning activities such as class projects or practical sessions. Aside from subject material integration, according to the informant 1 , there were other methods to inculcate multicultural values such as: (1) the custom of singing the national anthems before class started. This activity taught students to love their nation and its diversity, (2) reminding them to always maintain their fellowship among each other, (3) encouraging Muslim students to congregationally pray Dzuhur in order to fortify their faith since an early age. Meanwhile, the $6^{\text {th }}$ grade students were required to demonstrate the movements of Dhuha prayer. All of these activities were conducted by conditionings in accordance to the informant 2's statement as follows:

"Multicultural learning through character development should be managed in degrees through a lot of conditioning. Later on, it will likely turn into habits. For example, students would spontaneously lend sarong to others who forgot to bring it themselves. Besides, they slowly understood that they should not disturb those who were praying. Another instance, they were always taught about mutual respect, in this case, it was always in their mind to keep the Musala clean for the next people to pray. Well, this is what we called conditioning, starting from the smallest and simplest thing." 
From the above statement, conditioning was believed to be the most important factor in inculcating multicultural values in Islamic teachings.

\section{Learning Media}

Learning media used by the school were compulsory and supporting books such as Students' Worksheet, textbooks from the government as well as environment and students' real life experiences. There were also media that required teachers' creativity such as projected visual dynamic media, i.e. movies, television, videos, focus group, etc. Besides, there were banners of slogans all around the school such as "As long as we have determination and spirit, it is never too late for a new beginning", "We are brothers and sisters despite our differences", etc.

\section{Communicants (Students)}

Based on interviews with the informant 1 and the informant 2, students demonstrated abilities, such as: (1) being creative and innovative in learning, (2) exhibiting desire to be successful, (3) respecting and honoring every individual at school from teachers to the cleaning staff, (4) being able to adapt well in every change of science of technology development and in this case, teachers would always remind them to use it in a positive manner, and (5) feeling comfortable to ask questions and give critical opinions in regards to IECD learning. To conclude, conditioning, learning and enculturation are paramount to successfully educate elementary students. It can be clearly described by the following diagram:

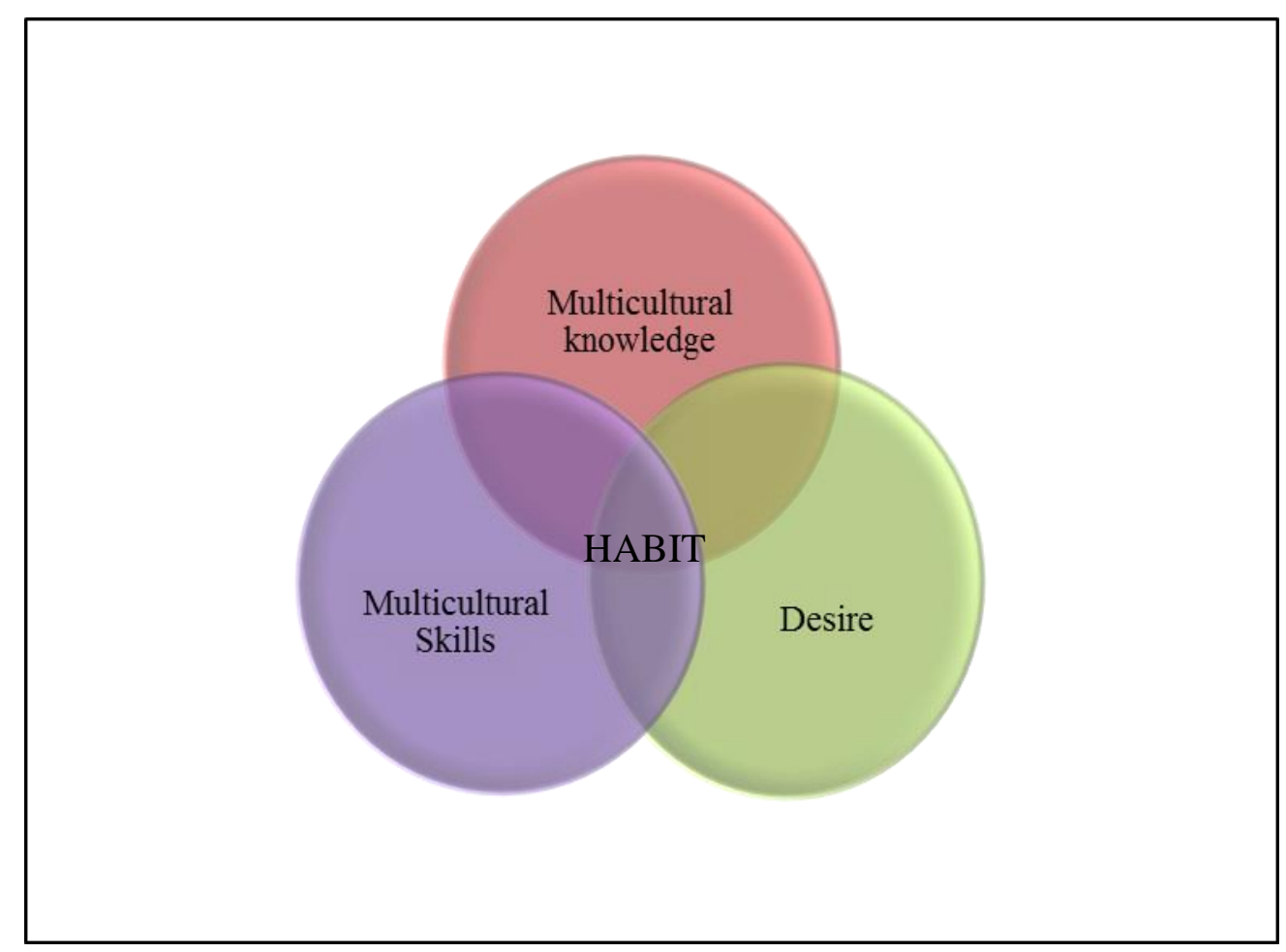

Figure 1. Effective Habits (Internalized Principles and Patterns of Behavior)

Continuous conditioning of students would eventually lead to the transformation of their habits and mindset in accordance with Islamic principles. This integration of habits into the IECD subject can be further described by Stephen Covey's Theory of Seven Habits. He claims that habit is the intersection of knowledge (what to do), skills (how to do) and desire (want to do). Knowledge is a theoretical paradigm on what to do and why to do it, and skills mean how to do it. Meanwhile, desire is a motivation to do 
something. These three components are the foundation of one's habit. The implementation of this theory into multicultural learning can be described as follows:

\section{a. Proactive}

Recognize that everyone is responsible for the things that happen in their lives and it means that we should not blame external factors. Proactive people have an inherent ability to make their own decision and be responsible for its consequence. In this case, the inculcation of multicultural values into IECD would indirectly help students to develop proactive habit since an early age. For example, they were always reminded to keep the classroom clean.

b. Begin with the End in Mind

Start with a clear destination in mind. Students were taught to realize that there will be afterlife. Consequently, they were taught to always be responsible for everything they do, to always use time wisely, to study hard, etc. as a provision for the afterlife.

\section{c. Put First Things First}

Prioritizing the most important thing that requires integrity, discipline and commitment. For instance, students were taught to put their responsibilities above their personal rights. Also, they were always reminded to study first before having a play time. More importantly, they were taught to pray promptly after they heard Adzan.

\section{d. Think Win/Win}

The mindset that continuously seeks mutual benefits in every human interaction. It is a belief in the Third Alternative rather than the first and second alternatives. Win/win perceives life as a cooperative arena instead of a competitive one. This mentality can be developed by, for example, tolerance, mutual respect and altruism.

\section{e. Seek First to Understand Then to be Understood}

A habit that works based on empathic communication principle. This is the key of effective interpersonal communication. In this case, students were encouraged to develop tolerance, altruism, nonjudgmental, open-mindedness, compassion and impartiality. In this context, humanity is strongly upheld.

\section{f. Synergize}

Understanding and valuing differences in another person's perspective, idea and willing to share them. Synergize means putting others' needs above ourselves, thinking win/win and nobody loses. For instance, students were encouraged to be cooperative and interdependent in righteousness as expressed in Islamic teachings.

\section{g. Sharpen the Saw}

This means having a continuous self-renewal in the four areas of your life-physical, spiritual, mental and social/emotional. The first three dimensions are related to habits 1-3 (proactive, begin with the end in mind and put first things first) that focus on the principles of vision, leadership and personal management. Lastly, the social and emotional dimension focuses on habits 4-6 (think win/win, seek first 
to understand then to be understood and synergize) regarding leadership, empathic communication and interpersonal creative cooperation. Hence, students were encouraged to possess good leadership accompanied with the ability to cooperate with others as well as demonstrate empathic communication with them. Hopefully, these seven habits will eventually develop delightful, responsible and empathic individuals who will function well either in family, school or the society as they grow up.

\section{Effect and Feedback}

In order to find out the learning effect, there are 3 areas that require assessment:

\section{a. Cognitive Area}

This area includes brain activities in processing knowledge. The assessment can be attained by doing these following activities:

- Quran recitation

- Identify, generalize and conclude. For example, students were asked to give examples of the Prophets' noble behaviors.

- Specify and elaborate subject matters such as the differences of Sadaqa and Zakat, etc.

\section{b. Affective Area}

This area is related to attitudes and values. It can be depicted from the implementation of ethic and aesthetic norms and values in everyday life such as demonstrating the right movements of Shalat.

\section{c. Psychomotor Area}

This area is related to skills or one's ability to act after they receive a certain learning experience. This psychomotor learning outcome is the extension of cognitive (understanding) and affective learning outcomes. Overall, learning competencies of elementary students can be described by the following table:

Table 3. The Qualifications of Knowledge, Attitudes and Skills

\begin{tabular}{|l|l|}
\hline Dimension & \multicolumn{1}{|c|}{ Qualifications } \\
\hline Knowledge & $\begin{array}{l}\text { Possessing factual and conceptual knowledge based } \\
\text { on their curiosity towards science, technology, art } \\
\text { and culture in terms of humanity, nationalism, } \\
\text { patriotism and civilization related to phenomena and } \\
\text { events at home, school and playgrounds. }\end{array}$ \\
\hline Attitudes & $\begin{array}{l}\text { Possessing behaviors that reflected the attitude of a } \\
\text { believer who has noble character, knowledge, } \\
\text { confidence and responsibility in order to be able to } \\
\text { effectively interact with others in social and natural } \\
\text { environment, home, school and playground. }\end{array}$ \\
\hline Skills & $\begin{array}{l}\text { Possessing the ability to think and act productively } \\
\text { and creatively in abstract and concrete aspects } \\
\text { according to their assignments. }\end{array}$ \\
\hline
\end{tabular}




\section{Communication Barriers}

There were some obstacles in the implementation of multicultural educational communication at SD BPI Bandung, especially in IECD teachings such as: (1) Language and communication barriers. It was not easy to solely give verbal explanation in the classroom about the materials. These students required modelling and conditioning, and (2) Misperception coming from parents. They felt rather uncomfortable with the current curriculum due to its differences to the former one. Overall, the research results can be described in the following diagram:

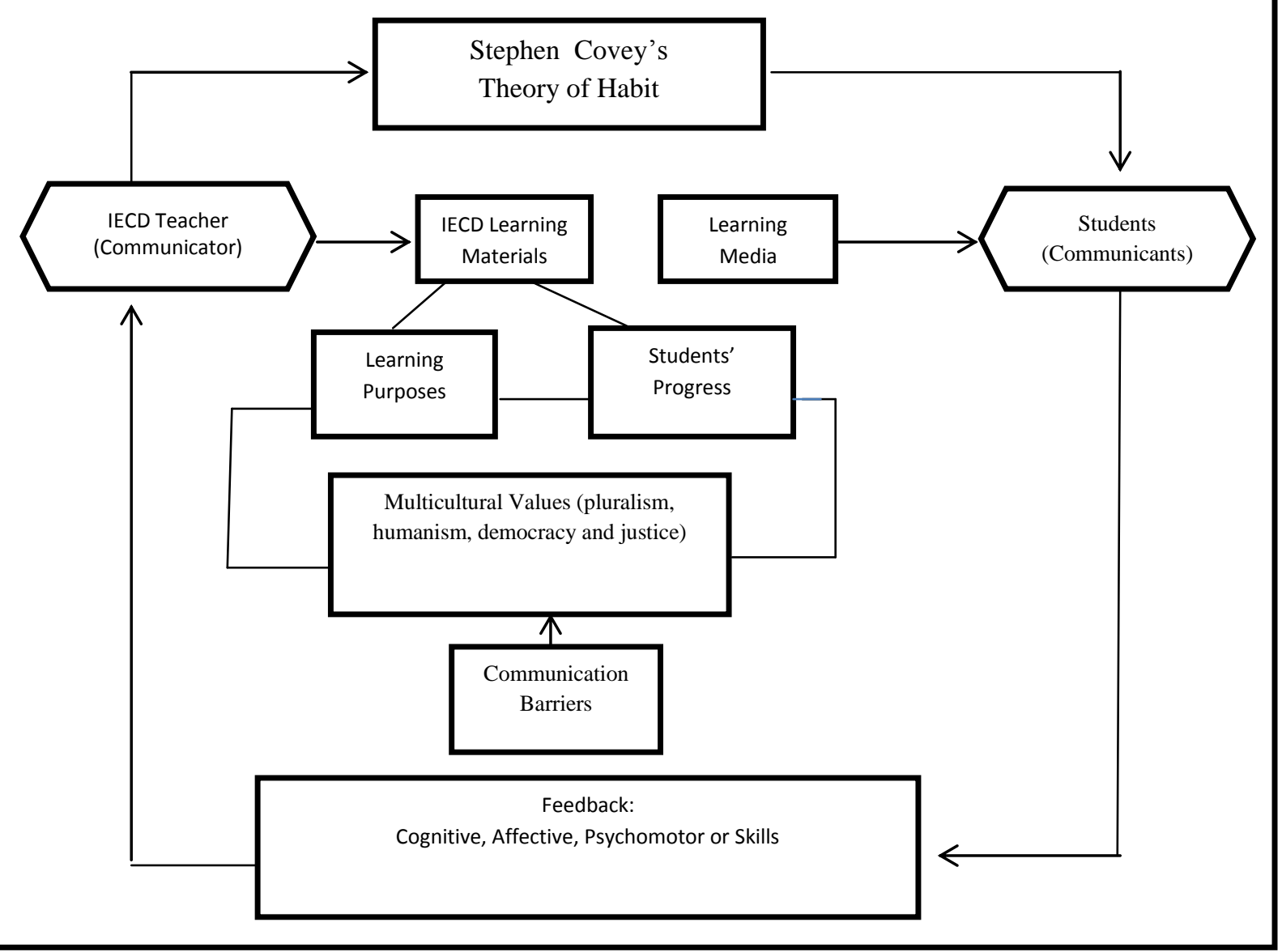

Figure 2. Research Findings

\section{Disscusion}

Multicultural educational communication that is applied in elementary schools through integrated learning of Islamic Education and Character Development (IECD) has become an urgent matter to be implemented in real life as a response to the diversity that we see among our society starting from the whole elements of educational communication itself, i.e. communicators, learning materials, media, communicants and effect (the development of behavior). It starts with the implementation and application of learning and knowledge through IECD teaching which aims not only to fortify students' faith in their religion but also manifest it into heterogeneities around them so that they develop tolerance, sympathy, empathy as well as mutual respect and honor. Thus, teaching and learning activities are not solely meant for students to master as much knowledge as possible but rather how they grow in the process of learning 
itself either in their classroom or at school in general. This effort will be successfully accomplished if students are accustomed to these values to an extent that it has become their habit and routine. This starts with transforming one's attitude positively towards diversity. The transformation must also occur at a school level as an entity that involves all of its elements and is supported by the government.

\section{Conclusions}

Multicultural educational communication should be developed in elementary schools as it is children's first foundation in preparation for the next level of their education. This multicultural teaching aims to develop students' sense of mutual respect and honor to cultural diversity. In this context, the multicultural values are integrated through IECD at SD BPI Bandung by involving educational communication elements, i.e.: 1) teacher as a communicator with multicultural mindset; 2) Islamic education teaching materials that is based on the curriculum that contains multicultural values such as pluralism, humanism, democracy and justice; 3) Various learning media that provides equal and impartial opportunities to all students to voice their opinions, think critically, and hence, respect those of different opinions and create harmonious relationship among them; 4) The communicants (students) are encouraged to able to adapt to diverse situation and condition. Overall, this implementation process must comply with Covey's theory of habits. Islamic education must also be able to internalize in students' awareness at the deepest level. In other words, this educational strategy does not only aim to fortify one's belief in their religion, but also develops their senses of empathy, sympathy and solidarity with others, making them an inseparable part of their daily lives in a heterogeneous culture.

\section{References}

Aufin, Mohammad. (2014). Sintesa Pendidikan Karakter dan Multikultural bagi Lingkungan Pendidikan Tinggi. Jurnal Psikologi. September, Vol II No 2: 110-125.

Chomaidi dan Salamah. (2018). Pendidikan dan Pengajaran Strategi Pembelajaran Sekolah, Jakarta: Grasindo.

Hakim, Al dan Sri Untari. (2018). Pendidikan Multikultural: Strategi Inovatif Pembelajaran Dalam Pluralitas Masyarakat Indonesia. Malang: Madani Media.

Ibrahim, Rustam. (2013). Pendidikan Multikutural: Pengertian, Prinsip, dan Relevansinya dengan Tujuan Pendidikan Islam. Jurnal Addin Vol 7 No 1: 129-154.

Jiyanto, Amiroel Eko Effendy. (2016). Implementasi Pendidikan Multikultural di Madrasah Inklusi Madrasah Aliyah Negeri Maguwoharjo Yogyakarta. Jurnal Penelitian V 10, P: 25-43.

Kartikawati, Dwi; Radjagukguk, Djudjur Lucianaand Sriwartini, Yayu (2018). Penanaman Nilai-Nilai Multikultural Melalui Komunikasi Pendidikan Di Sekolah Dasar Inklusi Di Yogyakarta Dan Surakarta. Widya Komunika, [S.L.], V. 8, N. 2, P. 58-75, Oct. 2018. ISSN 0216-7239.

Marwan, Saridjo. (1996). Bunga Rampai Pendidikan Agama Islam, Jakarta: Amissco: 37-63. 
Muhaimin et.al. (2008). Paradigma Pendidikan Islam Upaya mengefektifkan Pendidikan Agama Islam di Sekolah. Bandung: Remaja Rosdakarya.

Ruben, Brent D and Stewart, Lea P. (2008). Communication and Human Behaviour,USA:Alyn and Bacon.

Sapendi, Sapendi. (2015). Internalisasi Nilai-nilai Multikultural dalam Pembelajaran Pendidikan Agama Islam di Sekolah (Pendidikan Tanpa Kekerasan).

Raheema: Pusat Studi gender dan Anak, Vol 2 No 1: 88-110.

SM, Ismail. (2009). Strategi Pembelajaran Agama Islam Berbasis PAIKEM: Pembelajaran Aktif, Inovatif, Kreatif, Efektif, Dan Menyenangkan. Semarang: Rasail Media Group.

Tilaar, H. A. R. (2003). Kekuasaan dan Pendidikan: Suatu Tinjauan dari Perspektif Studi Kultural. Magelang: Indonesia Tera.

Yusuf, M Pawit. (2010). Komunikasi Instruksional: Teori dan Praktek. Jakarta: Bumi Aksara.

Yin, Robert K. (2004). Studi Kasus : Desain \& Metode. Jakarta : RajaGrafindo Persada Zubaidi. (2017). Strategi Taktis Pendidikan Karakter (Untuk PAUD dan Sekolah), Depok: Radja Grafindo Persada.

\section{Copyrights}

Copyright for this article is retained by the author(s), with first publication rights granted to the journal.

This is an open-access article distributed under the terms and conditions of the Creative Commons Attribution license (http://creativecommons.org/licenses/by/4.0/). 